JGRADASI TEKnIK SIPIL 


\section{JURNAL GRADASI TEKNIK SIPIL POLITEKNIK NEGERI BANJARMASIN}

Jurnal Gradasi Teknik Sipil diterbitkan oleh Pusat Penelitian dan Pengabdian Kepada Masyarakat Politeknik Negeri Banjarmasin. Ruang lingkup makalah meliputi Bidang Teknik dan Manajemen dengan konsentrasi Bidang Transportasi, Geoteknik, Struktur, Keairan dan Manajemen Konstruksi. Isi makalah dapat berupa penyajian isu aktual di bidang Teknik Sipil, review terhadap perkembangan penelitian, pemaparan hasil penelitian, dan pengembangan metode, aplikasi, dan prosedur di bidang Teknik Sipil. Makalah ditulis mengikuti panduan penulisan.

\section{Penanggung Jawab}

Nurmahaludin, ST, MT.

\section{Dewan Redaksi}

Ketua :

Anggota : Riska Hawinuti, ST, MT.

Nurfitriah, S.Pd, MA.

Ir. Rusliansyah, M.Sc.

\section{Reviewer}

Dr. Ir. Yanuar Jarwadi Purwanto, MS. (Institut Pertanian Bogor)

Dr. Ir. Achmad Rusdiansyah, MT. (Universitas Lambung Mangkurat)

Dr. Ir. M. Azhar, M. Sc. (Institut Sains dan Teknologi Nasional)

Dr. Ir. Endang Widjajanti, MT. (Institut Sains dan Teknologi Nasional)

Joni Irawan, ST, MT. (Politeknik Negeri Banjarmasin)

Yusti Yudiawati, ST, MT. (Politeknik Negeri Banjarmasin)

\section{Editing dan Tata Bahasa}

Nurfitriah, S.Pd., MA.

\section{Desain dan Tata Letak}

Abdul Hafizh Ihsani

\section{Alamat Redaksi}

Jurusan Gradasi Teknik Sipil Politeknik Negeri Banjarmasin, Jl. Brigjen H. Hasan Basri 70123 Banjarmasin Telp/Fax 0511-3307757; Email: gradasi.tekniksipil@poliban.ac.id 


\section{JURNAL GRADASI TEKNIK SIPIL}

\section{DAFTAR ISI}

Perencanaan Campuran Lapis Aspal Beton Permukaan Dengan Asbuton Butir Sebagai Filler ...( 1 - 9 )

Surat, Rifanie Gazalie, Pazilatul Mumamiroh

Pengaruh Keberadaan Pasar Sungai Lulut Terhadap Kinerja Jalan Martapura Lama KM. 05 ...( 10 - 19)

\section{Riska Hawinuti}

Analisis Perbandingan Biaya Penggunaan Perancah Kayu Galam Dan Perancah Besi (Scaffolding) ...( $20-32)$ Aunur Rafik, Rinova Firman Cahyani

Tinjauan Debit Andalan untuk Irigasi di Kecamatan Sungai Tabuk Kabupaten Banjar ...( $33-43)$

Fakhrurrazi, Herliyani Farial Agoes, Desi Anggeriyani

Ekosemen Sebagai Media Perekat Pengganti Semen Untuk Beton ...( 44 - 51 ) Marhadi Sastra, Juli Ardita Pribadi R

Pengaruh Posisi, Jumlah Layer Dan Mutu Kayu Terhadap Balok Laminasi Kayu Mahang Dan Kayu Meranti ...( 52 - 60 )

\section{Indriyani Puluhulawa}

Visualisasi Dan Identifikasi Pola Retak Dinding Bata Akibat Penurunan Pondasi Struktur Bangunan Di Kota Banjarmasin ...( 61 - 68 )

\section{Darmansyah Tjitradi, Eliatun}

Pengembangan Perumahan Dengan Desain Konstruksi Dilahan Basah Pada Wilayah Kota Banjarmasin Menggunakan Riset Operasi ...( 69 - 75 )

\section{Eliatun, Darmansyah Tjitradi}




\title{
Pengaruh Posisi, Jumlah Layer dan Mutu Kayu Terhadap Balok Laminasi Kayu Mahang dan Kayu Meranti
}

\author{
Indriyani Puluhulawa ${ }^{1 *}$ \\ ${ }^{1,2}$ Dosen Jurusan Teknik Sipil Politeknik Negeri Bengkalis \\ e-mail: *1 indriyani_p@polbeng.ac.id (corresponding author)
}

\begin{abstract}
Abstrak
Keterbatasan hasil hutan yang mulai berkurang membuat kayu berdimensi besar dan mempunyai mutu tinggi sulit didapatkan. Salah satu alternatif untuk mengatasi masalah tersebut adalah dengan melakukan rekayasa laminasi dengan menggabungkan lapis-lapis kayu kualitas berbeda menjadi balok berukuran tertentu sesuai keinginan. Jenis kayu dan posisi tiap layer diduga berpengaruh terhadap kapasitas balok laminasi. Tujuan penelitian ini adalah untuk mengetahui kapasitas lentur (MOR) balok laminasi kayu Mahang dan Meranti yang divariasikan layernya kemudian dibandingkan dengan balok solidnya. Ada 3 jenis benda uji laminasi yang dibuat dengan dimensi $5 \times 7 \times 76 \mathrm{~cm} 3$ yang terdiri dari 7 layer, balok BL K1 terdiri dari 2 layer kayu meranti di bagian atas dan bawah serta 5 layer kayu mahang di tengah. Balok BL K2 terdiri dari 4 layer kayu meranti dibagian atas ddan bawah serta 3 layer kayu mahang di tengah. Balok BL K3 terdiri dari 6 layer kayu meranti di bagian atas dan bawah serta 1 layer kayu mahang di tengah. Hasil pengujian menunjukkan bahwa penggunaan kayu dengan berat jenis yang lebih tinggi pada layer terluar akan meningkatkan kapasitas lentur (MOR) dan modulus elastisitas (MOE). Selain itu, dalam proporsi jumlah yang sama atau lapisan yang lebih besar antara kayu mahang dan meranti, menunjukkan peningkatan MOR dan MOE balok laminasi dibandingkan dengan balok solid yang memiliki berat jenis rendah (Mahang).
\end{abstract}

Kata kunci-balok laminasi, jumlah layer, mutu kayu

\begin{abstract}
Reduced forest products cause also reduced of large-dimensional wood that has high quality. One alternative to solve the problem is by doing laminate engineering by combining different quality wooden layers into specific sized beams as desired. The type of wood and the position of layer give effect to the laminate beam capacity. The aim of this research was to find out the flexural capacity (MOR) of Mahang and Meranti wood laminated beams which layers were varied which then the result of the laminated beam was compared with the solid beams. There were 3 types of laminate specimens made with dimension $5 \times 7 \times 76 \mathrm{~cm} 3$ which consisted of 7 layers; BL K1 beam consisted of 2 layers of Meranti wood at the top and bottom of the beam and 5 layers of Mahang in the middle; BL K2 beam consisted of 4 layers of Meranti wood at the top and bottom of the beam, and 3 layers of Mahang in the middle; and BL K3 beam consisted of 6 layers of Meranti wood at the top and bottom of the beam and 1 layer of Mahang in the middle. The test results showed that the use of wood of higher specific gravity at the outermost layer has increased the flexural capacity (MOR) and modulus of elasticity (MOE), particularly in laminated beams (Meranti wood and Mahang wood) with the same numbers of layers. Moreover, in same number or greater layer proportion between Mahang and Meranti wood, the result showed the increased of MOR and MOE of laminated beams compared with solid beam that has low specific gravity (Mahang).
\end{abstract}

Keywords - laminated beam, number of layers, quality of wood 


\section{PENDAHULUAN}

Penggunaan kayu sebagai bahan struktural diantaranya adalah untuk keperluan bahan bangunan rumah, pembuatan kuda-kuda, rangka jembatan, dan lain-lainnya. Untuk berbagai keperluan struktural tersebut dibutuhkan dimensi kayu yang cukup besar dengan bentang yang panjang. Namun untuk memperoleh kayu bermutu baik dan ukuran yang relatif besar semakin sulit ditemui dipasaran karena semakin menipisnya produksi hasil hutan.

Alternatif untuk mengatasi kekurangan kayu dari hutan alam adalah menggunakan kayu dari hutan rakyat (HR). Namun kayu yang dijual di pasaran memiliki dimensi (panjang dan lebar) yang terbatas, sehingga diperlukan suatu produk rekayasa agar membuat kayu ini memiliki dimensi yang besar. Produk rekayasa tersebut adalah balok laminasi.

Balok laminasi (Glulam Beam) merupakan produk rekayasa yang terdiri dari dua atau lebih lapisan kayu (lamina) yang saling direkat dalam arah serat longitudinal (Moody et al. 1999).

Di daerah Bengkalis banyak tumbuh jenis tanaman kayu seperti kayu rambutan, kayu durian, kayu nangka, kayu rambai, kayu kelapa, kayu meranti merah dan kayu mahang. Sebagian masyarakat sekitar daerah Bengkalis menggunakan kayu jenis tersebut untuk digunakan sebagai bahan bangunan.

Kayu meranti merupakan salah satu jenis kayu khas daerah tropis yang cukup terkenal. Kayu ini termasuk salah satu jenis kayu komersil yang banyak peminatnya. Di pasaran kayu meranti dikenal memiliki tiga jenis yang berbeda, yakni meranti merah, meranti putih, dan meranti kuning. Kayu meranti merah tergolong kayu keras berbobot ringan sampai sedang. Berat jenisnya berkisar antara $0,3-0,86$ pada kandungan air $15 \%$. Kayu terasnya berwarna merah muda pucat, merah muda kecoklatan, hingga merah tua atau bahkan merah tua kecoklatan. Menurut kekuatannya, jenis-jenis meranti merah dapat digolongkan dalam kelas kuat II-IV; sedangkan keawetannya tergolong dalam kelas III-IV.
Kayu Mahang merupakan jenis kayu yang relatif ringan dan memiliki tingkat keawetan yang agak rendah. Kayu ini umumnya memiliki densitas yang berkisar antara $270-500 \mathrm{~kg} / \mathrm{m}^{3}$ pada kadar air $15 \%$. Memiliki batang bulat, halus, dan berwarna agak abu-abu kehijauan. Diameter batang dapat mencapai $70 \mathrm{~cm}$ dan kadang-kadang berbanir tetapi kecil. Kayunya ringan dengan berat jenis (BJ) 0,45. Kelas keawetan V dan kelas kekuatan III.

Penelitian ini mencoba untuk meningkatkan efesiensi penggunaan bahan baku kayu meranti sebagai kayu keras dan meningkatkan mutu dari kayu mahang sebagai kayu ringan sehingga dapat digunakan untuk kayu struktural dengan cara membuat balok laminasi kayu Meranti dan kayu Mahang.

Tujuan utama penelitian ini ialah untuk menentukan berapa kapasitas dari balok laminasi kayu Meranti dan kayu Mahang jika dilakukan variasi posisi layer/laminanya.endahuluan pada artikel ilmiah membahas mengenai latar belakang masalah, tinjauan pustaka secara ringkas, maksud dan tujuan riset dilakukan.

\section{METODE PENELITIAN}

A. Waktu dan Tempat Penelitian

Penelitian ini dilakukan di Laboraturim Uji Bahan Program Studi Teknik Sipil dan Laboraturim Uji Bahan Program Studi Teknik Mesin Politeknik Negeri Bengkalis. Waktu penelitian dilakukan selama 3 bulan, yaitu bulan Juni s/d Agustus 2017.

\section{B. Alat dan Bahan Penelitian}

Adapun peralatan yang digunakan dalam penelitian ini adalah gergaji mesin, mesin ketam, klamp, Mesin Uji Lentur, Mesin Kuat Tekan, Mesin Kuat Tarik, timbangan dan oven.

Bahan yang digunakan adalah kayu Mahang dan kayu Meranti yang diperoleh dari pedagang kayu yang ada pulau Bengkalis serta perekat berupa lem Epoxy dengan Merk Q-Bond.

C. Pembuatan Benda Uji

Sebelum pembuatan benda uji baik properties material maupun balok laminasi terlebih dahulu dipastikan kadar air kayu yang sudah dikeringkan 
harus $<16 \%$. Langkah selanjutnya adalah proses pembuatan benda uji properties material baik untuk kayu Mahang dan kayu Meranti. Untuk pembuatan benda uji laminasi, langkah-langkah pembuatannya sebagai berikut :

a. Kayu mahang dan kayu meranti dipotong dengan ukuran lebar $5 \mathrm{~cm}$, tebal $1 \mathrm{~cm}$ dan panjang $76 \mathrm{~cm}$ sebanyak yang diperlukan.

b. kayu yang sudah dipotong kemudian diketam, pengetaman dilakukan untuk meghilangkan serabut sisa pemotongan kayu.

c. Kemudian dilakukan penghalusan muka kayu dengan cara pengamplasan.

d. selanjutnya tiap layer/lamina yang sudah cukup halus direkatkan dengan lem Epoxy

e. Setelah direkatkan, balok laminasi dijepit dengan menggunakan klamp selama 4 jam untuk memastikan perekatan antara layer.

Jumlah layer/lamina balok laminasi sebanyak 7 lapis kayu, kayu Meranti ditempatkan pada layer terluar, hal ini dilakukan mengingat mutu kayu Meranti lebih kuat dibandingan dengan kayu Mahang (Puluhulawa, 2018), sehingga kayu Meranti dapat bekerja maksimal untuk memikul tarik pada bagian bawah balok dan tekan pada bagian atas balok, sesuai dengan konsep diagram tegangan lentur balok seperti Gambar 1 .

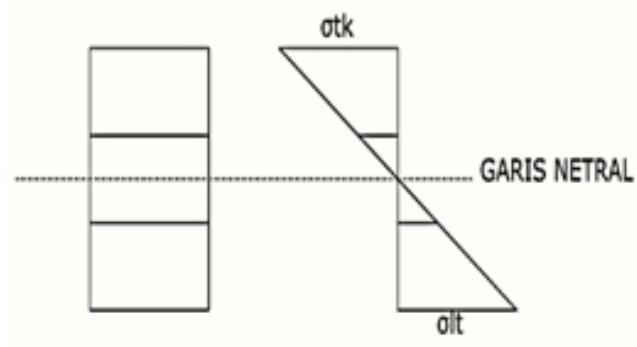

Gambar 1. Diagram Tegangan Lentur Balok

Dan untuk layer bagian tengah diisi dengan kayu Mahang. Variasi layer dari balok laminasi lebih detail dapat dilihat pada gambar berikut:

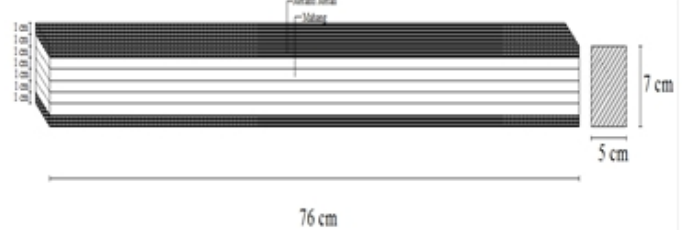

Gambar 2. Balok laminasi kayu meranti merah dan kayu mahang kombinasi 1 dengan 5 layer kayu Mahang ditengah (BL K1)

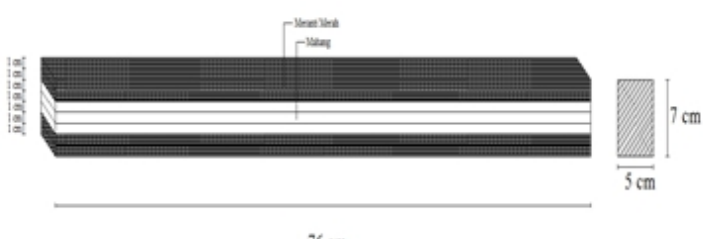

$76 \mathrm{~cm}$

Gambar 3. Balok laminasi kayu meranti merah dan kayu mahang kombinasi 2 dengan 3 layer kayu Mahang ditengah (BL K2)

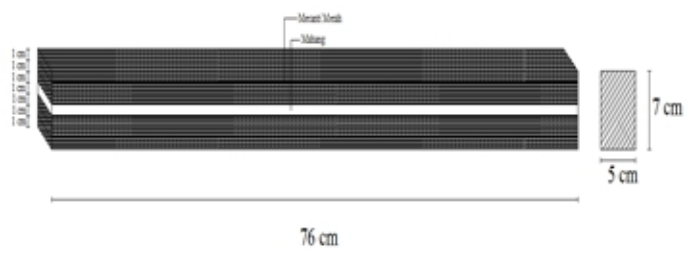

Gambar 4. Balok laminasi kayu meranti merah dan kayu mahang kombinasi 3 dengan 1 layer kayu Mahang ditengah (BL K3)

D. Pengujian Sifat Fisik Kayu Mahang dan Kayu Meranti

Pengujian sifat fisik yang dilakukan terdiri atas pengujian kadar air dan berat jenis yang berdasarkan SNI 03-6850-2002. Benda uji kadar air dan berat jenis punya dimensi yang sama yaitu $5 \mathrm{x}$ 5 x $5 \mathrm{~cm}$. Besarnya nilai kadar air dihitung dengan Persamaan (1), dimana nilai kadar air standar tidak lebih besar dari $16 \%$.

$$
K A=\frac{B A-B K O}{B K O} \times 100 \%
$$

Dimana:

$\mathrm{KA}=$ Kadar air kayu (\%)

$\mathrm{BA}=$ Berat awal (gram)

$\mathrm{BKO}=$ Berat kering oven $($ gram $)$

E. Pengujian Sifat Mekanik Kayu Mahang dan Kayu Meranti

Pengujian sifat mekanik yang dilakukan terdiri atas pengujian kuat tekan sejajar arah serat dan kuat tekan tegak lurus arah serat yang berdasarkan pada SNI 03-3958-1995 dengan dimensi benda uji $5 \times 5 \times 20 \mathrm{~cm}$ untuk pengujian kuat tekan sejajar arah serat dan $5 \times 5 \times 15 \mathrm{~cm}$ untuk pengujian kuat tekan tegak lurus arah serat.

Pengujian sifat mekanik lainnya yaitu pengujian kuat geser kayu, dimana seperti diketahui bahwa 
pengujian kuat geser adalah untuk menentukan seberapa besar kayu mampu menahan beban yang membuat bagian kayu tergeser dari bagian lainnya. Pengujian ini didasarkan atas SNI 03-3400-1994 dengan dimensi benda uji dapat dilihat pada Gambar 5 berikut. Besarnya nilai gaya geser kayu dapat dihitung dengan Persamaan (2).

$$
f s / /=\frac{P}{b x h}
$$

$$
\begin{aligned}
& \text { Dimana : } \\
& \mathrm{fs} / /=\text { Kuat geser (Mpa) } \\
& \mathrm{P} \quad=\text { Beban maksimum } \\
& \mathrm{b} \quad=\text { Lebar } \\
& \mathrm{h} \quad=\text { Tinggi }
\end{aligned}
$$

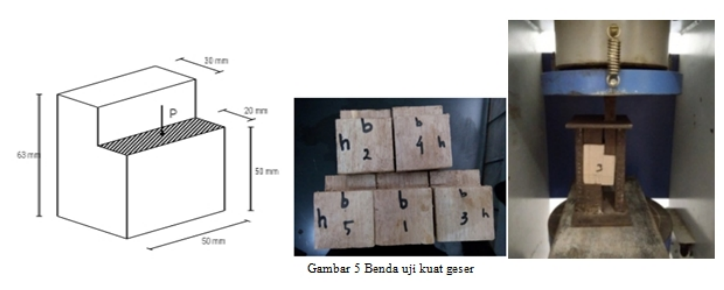

Pengujian lain ialah pengujian kuat lentur kayu yang mengacu kepada SNI 03-3959-1995. Selain itu dilakukan juga pengujian lentur untuk balok solid yang mempunyai dimensi sama dengan balok laminasi, untuk dibandingkan hasilnya dengan balok laminasi. Besarnya nilai kuat lentur balok kayu bisa dihitung dengan Persamaan (3) berikut ini.

$$
f b=\frac{a P L}{2 b h^{2}}
$$

$$
\begin{aligned}
& \text { Dimana : } \\
& \mathrm{fb}=\text { Kuat lentur (Mpa) } \\
& \mathrm{P} \quad=\text { Beban uji maksimum } \\
& \mathrm{L} \quad=\text { Jarak tumpuan } \\
& \mathrm{b} \quad=\text { Lebar benda uji } \\
& \mathrm{h} \quad=\text { Tinggi benda uji }
\end{aligned}
$$

Selain itu dilakukan juga pengujian tarik kayu. Pengujian ini bertujuan untuk mengetahui nilai kuat tarik kayu kayu Meranti dan Mahang, acuan yang digunakan dalam pengujian ini adalah SNI 033399-1994. Besarnya nilai kuat tarik kayu dapat ditentukan dengan Persamaan:

$$
f t=\frac{p}{b x h}
$$

Dimana:

$$
\begin{aligned}
\mathrm{ft} & =\text { Kuat tarik (Mpa) } \\
\mathrm{P} & =\text { Beban maksimum } \\
\mathrm{b} & =\text { Lebar dalam } \\
\mathrm{h} & =\text { Tinggi dalam }
\end{aligned}
$$

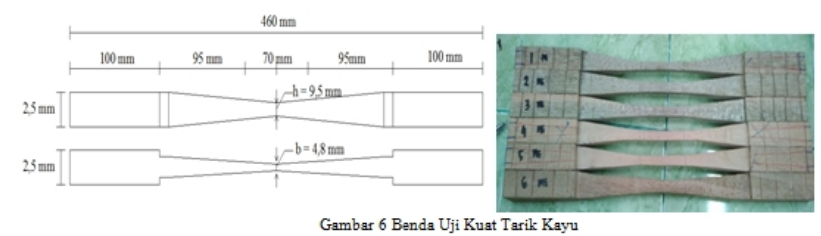

F. Pengujian sifat mekanik balok laminasi

1) MOR (Modulus of Rupture)

Pengujian ini menggunakan alat Mesin Uji Lentur, dengan ukuran benda uji $5 \times 7 \times 76 \mathrm{~cm}$ dengan jarak antar tumpuan $71 \mathrm{~cm}$ dan diberi beban satu titik di tengah bentang. Besarnya nilai MOR dapat dihitung dengan Persamaan (5) berikut ini:

$$
M O R=\frac{3 P L}{2 b h^{2}}
$$

\section{Dimana :}

$$
\begin{array}{ll}
\mathrm{MOR} & =\text { Kuat lentur (Mpa) } \\
\mathrm{P} & =\text { Beban uji maksimum } \\
\mathrm{L} & =\text { Jarak tumpuan } \\
\mathrm{b} & =\text { Lebar benda uji } \\
\mathrm{h} & =\text { Tinggi benda uji }
\end{array}
$$

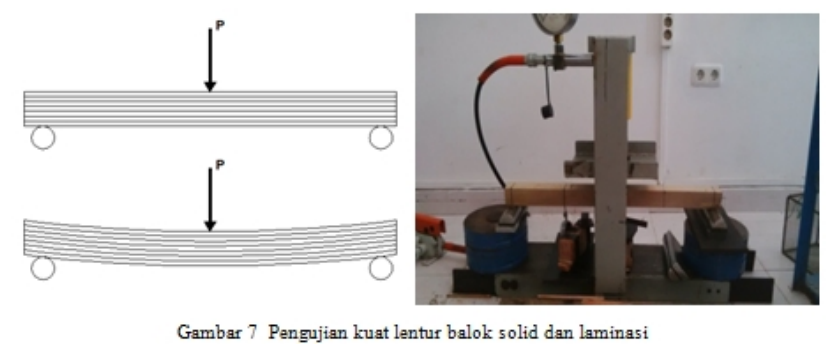

2) MOE (Modulus of Elasticity)

Pengujian MOE dilakukan bersama-sama dengan pengujian MOR, hanya saja pada saat pengujian MOR ditambahkan pencatatan lendutan untuk menentukan nilai MOE. Besarnya nilai MOE bisa dihitung dengan Persamaan 6. 


$$
M O E=\frac{P \times L^{3}}{4 \times \Delta \times b \times h^{3}}
$$

Dimana:

$\mathrm{P}=$ Beban

$\mathrm{L}=$ Panjang bentang pengujian balok

$\Delta=$ Lendutan maksimum di $1 / 2$ bentang

$\mathrm{B}=$ Lebar balok

$\mathrm{H}=$ Tinggi balok

\section{G. Nilai Desain Acuan}

Pemilahan secara visual harus mengikuti standar pemilahan secara visual yang baku. Nilai kuat acuan mekanik kayu dapat dilihat pada Tabel 2.2 berdasarkan pada nilai modulus elastisitas lentur acuan (Ew). Untuk hasil pengujian di laboratorium nilai kuat acuan dapat dihitung menggunakan Persamaan 7:

$$
F=\frac{F_{A v g}-(1,645, S T D)}{\gamma_{D L}} \gamma_{K A}
$$

Dengan :

F_Avg : Nilai rata-rata

STD : Nilai standar deviasi

$\gamma_{-}$DL $\quad$ Faktor lama pembebanan

$\gamma_{-}$KA $\quad$ : Faktor koreksi kadar air

Faktor koreksi lama pembebanan $\left(\gamma \_\right.$DL $)$ memperhitungkan time-dependent behavior kayu. Kayu memberi kekuatan tinggi untuk pembebanan dalam waktu singkat dan begitu pula sebaliknya. Faktor koreksi ini bernilai 1,0 untuk pembebanan dengan durasi 10 tahun. Sedangkan untuk pengujian di laboratorium dengan lama pembebanan sekitar 3 sampai 5 menit faktor koreksi bernilai 1,65. Faktor koreksi kadar air dianggap bernilai sama dengan 1,0 jika nilai kadar air rata-rata hasil pengujian berkisar antara 12\% hingga 15\% (Awaludin Ali, 2011).

\section{HASIL DAN PEMBAHASAN}

A. Pengujian Sifat Fisik Kayu Mahang dan Kayu Meranti

Awaludin dan Inggar (2005) menyatakan sifat sifat fisis kayu terdiri dari: kadar air, kepadatan dan berat jenis.

\section{1) Kadar Air}

Hasil pengujian menunjukan bahwa nilai kadar air kayu Mahang berkisar antara 13,01 - 14,39\% dan kadar air kayu Meranti berkisar antara 12,64 13,68\%. Hasil pengujian kadar air kayu Mahang dan kayu Meranti dapat dilihat pada Gambar 8.

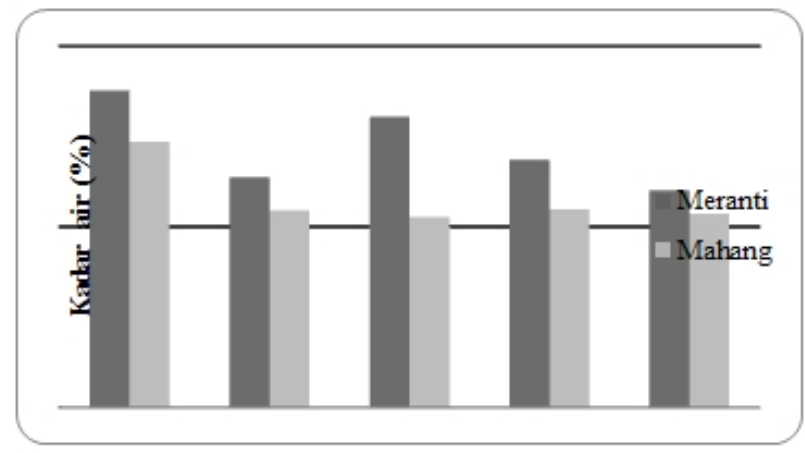

Gambar 8. Nilai kadar air kayu Mahang dan kayu Meranti

Pada Gambar 8 menunjukan kayu Mahang punya nilai rerata kadar air lebih kecil dibandingkan dengan kayu Meranti yaitu sebesar $12,89 \%$ dan untuk kayu Meranti 13,61\%.

Dari hasil pengujian kadar air tersebut dapat dilihat bahwa semua kayu yang digunakan untuk membuat balok laminasi memiliki kadar air yang lebih kecil dari 16\% yang disyaratkan untuk kayu laminasi. Dengan demikian kayu yang digunakan telah memenuhi syarat teknis laminasi, sebab kadar air yang tinggi akan menurunkan efek perekatan dan akan menyebabkan meningkatnya absorpsi kayu yang tinggi serta ikatan jadi lemah (Haygreen dan Bowyer, 1996).

\section{2) Berat Jenis}

Berat jenis kayu Mahang berkisar antara 0,34 0,38 dan berat jenis kayu Meranti berkisar antara $0,44-0,48$. Hasil pengujian berat jenis kayu Mahang dan kayu Meranti dapat dilihat pada Gambar 9. 


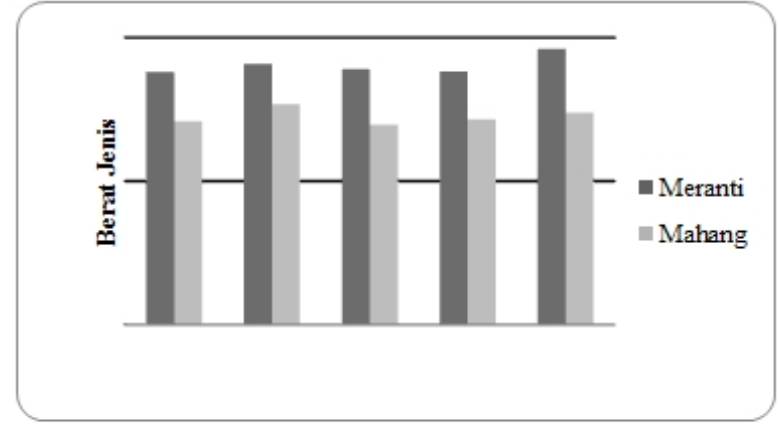

Gambar 9. Nilai berat jenis kayu Mahang dan kayu Meranti

Gambar 9 menunjukan bahwa kayu Mahang punya nilai rerata berat jenis lebih kecil dibandingkan kayu Meranti yaitu sebesar 0,36 dan kayu Meranti 0,45. Menurut Anshari (2006) kayu laminasi dapat dirancang dan dibuat dengan mengkombinasikan dua jenis kayu dengan kelas yang berbeda sehingga pemakaian kayu akan lebih efisien.Kayu dengan mutu yang lebih tinggi ditempatkan dibagian tepi yang menahan tegangan yang besar, sedangkan kayu dengan mutu yang lebih rendah ditempatkan di tengah, pada bagian yang akan menerima tegangan lebih kecil.

B. Pengujian sifat Mekanik kayu Mahang dan kayu Meranti

1) Kuat Lentur

Iensufrie (2009) menyatakan bahwa kuat lengkung atau kelenturan kayu adalah kemampuan kayu untuk melengkungkan diri ketika menahan tekanan diatasnya. Gambar 10 menunjukan bahwa kuat lentur kayu Mahang berkisar antara 26,95 30,04 Mpa dengan nilai rerata 28,36 Mpa. Kuat lentur kayu Meranti berkisar antara 38,07 - 41,03 Mpa dengan rerata 40,03 Mpa.

Hasil pengujian terhadap kuat lentur tersebut menunjukkan bahwa kayu Meranti memiliki struktur lentur yang lebih tinggi dibandingkan dengan kayu Mahang. Hasil ini juga didukung oleh data hasil pengujian berat jenis.

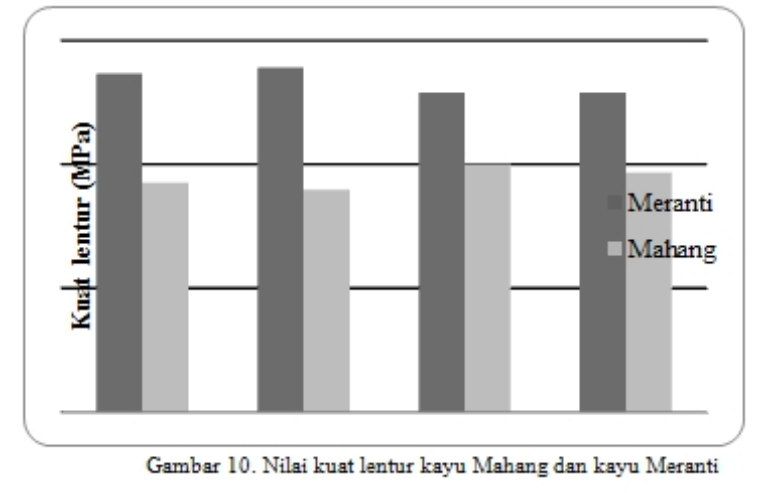

2) Kuat Geser

Hasil pengujian kuat geser kayu Mahang dan kayu Meranti dapat dilihat pada Gambar 11.

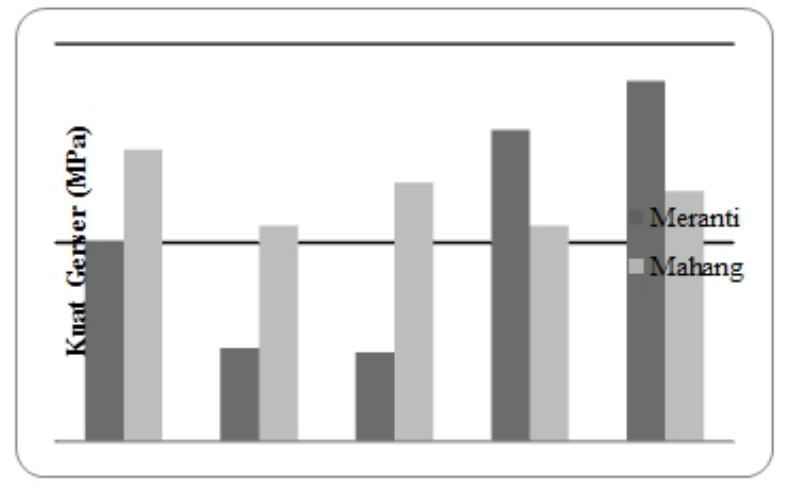

Gambar 11. Nilai kuat geser kayu Mahang dan kayu Meranti

Dari Gambar 11 diketahui bahwa kuat geser kayu Mahang berkisar antara 2,71 - 3,66 Mpa dengan nilai rerata kuat geser sebesar 2,65 Mpa. Untuk kayu Meranti kuat geser berkisar antara 1,12 - 4,53 Mpa.

\section{3) Kuat Tekan Tegak Lurus Serat dan Sejajar} Serat

Gambar 12 menunjukan bahwa nilai kuat tekan sejajar serat kayu Mahang berkisar antara 14,23 15,84 Mpa dengan nilai rerata 15,22 Mpa. Nilai kuat tekan sejajar serat kayu Meranti berkisar antara 13,32 - 15,98 Mpa dengan rerata 14,37 Mpa. 


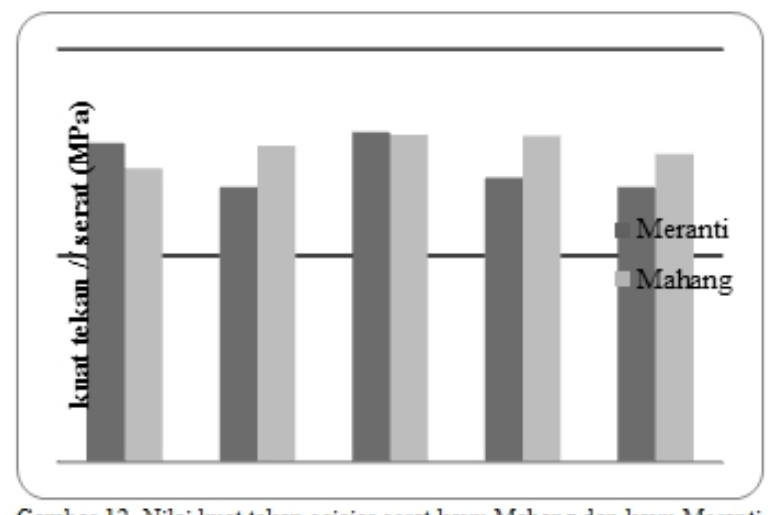

Gambar 12. Nilai kuat tekan sejajar serat kayu Mahang dan kayu Meranti

Gambar 13 menunjukan bahwa nilai kuat tekan tegak lurus serat kayu Mahang berkisar antara 2,19 - 4,46 Mpa dengan nilai rerata 3,59 Mpa. Nilai kuat tekan tegak lurus serat kayu Meranti berkisar antara 3,1 - 8,05 Mpa dengan rerata 5,89 Mpa.

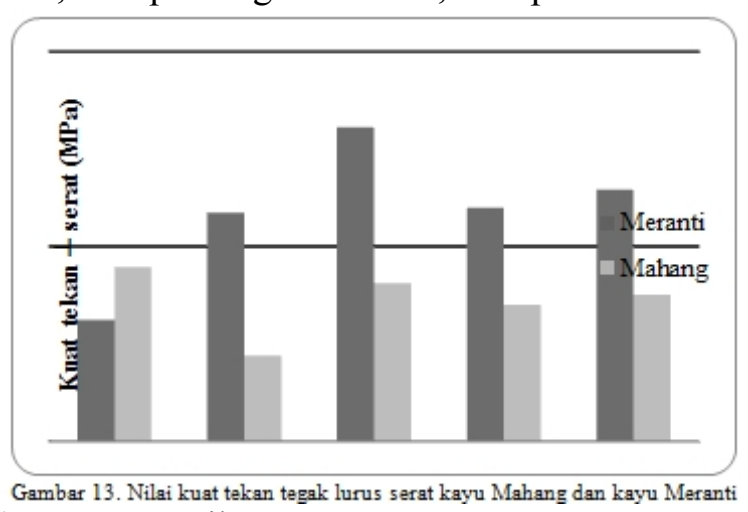

4) Kuat Tarik

Gambar 14 menunjukan bahwa nilai kuat tarik kayu Mahang berkisar antara 29,55 - 41,24 Mpa dengan nilai rerata 35,29 Mpa. Nilai kuat tarik kayu Meranti berkisar antara 66,25 - 69,32 Mpa dengan rerata 67,34 Mpa.

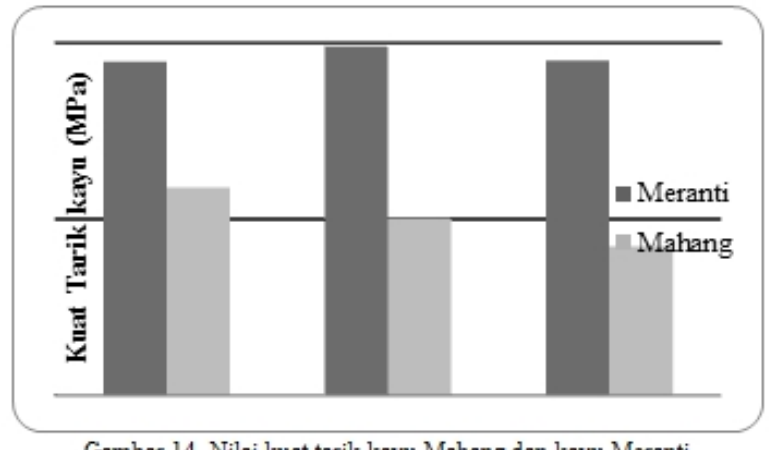

Gambar 14. Nilai kuat tarik kayu Mahang dan kayu Meranti
C. Pengujian Sifat Mekanik Balok Laminasi dan Balok Solid Kayu Mahang dan Kayu Meranti

1) MOR (Modulus of Rupture)

Pengujian balok laminasi didasarkan pada variasi posisi layernya dan mutu kayu penyusunnya. Ada 3 variasi balok laminasi, BL K1, BL K2 dan BL K3. MOR itu sendiri menunjukan kekuatan kayu dalam menahan beban yang bekerja padanya. Berdasarkan hasil pengujian MOR balok laminasi dan balok solid seperti yang ditunjukan pada Gambar 9 diketahui nilai MOR rerata BL K1 sebesar 6,54 Mpa, rerata BL K2 sebesar 18,96 Mpa dan rerata BL K3 21,31 Mpa. Hasil tersebut menunjukkan bahwa rerata MOR yang terbesar adalah pada variasi BL K3 (balok laminasi dengan 1 layer kayu Mahang di tengah).

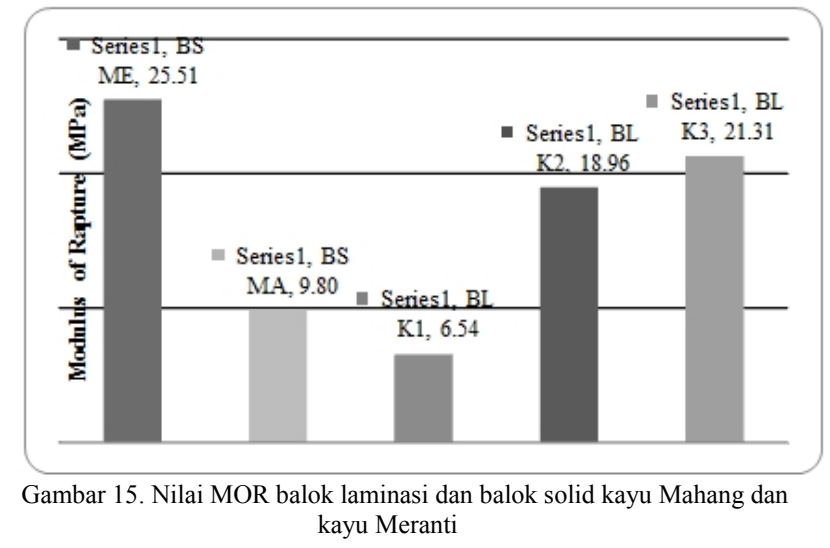

Dari Gambar 15 dapat dilihat bahwa pada BL K1 terjadi penurunan nilai rerata MOR sebesar 33\% jika dibandingkan dengan BS MA (balok solid kayu Mahang). Penurunan nilai rerata MOR juga terjadi pada BL K3 jika ditinjau terhadap BL ME (balok solid kayu Meranti) sebesar 16,4\%. Hal ini berarti bahwa penggunaan kayu Meranti dengan 1 layer terluar (atas dan bawah) tidak memberikan kontribusi terhadap kayu Mahang melalui teknologi laminasi. Dengan kata lain penggunaan mutu kayu yang berbeda tidak akan berdampak signifikan terhadap nilai MOR jika jumlah layer yang digabungkan tidak proporsional.

Kondisi ini bisa disebabkan oleh beberapa faktor diantaranya lekatan antar layer yang kurang sempurna, jumlah layer kayu Meranti yang lebih sedikit dan perbedaan berat jenis antar kedua kayu. 
Risnasari (2012) menyatakan bahwa semakin banyak layer maka nilai MOR balok laminasi yang dihasilkan akan semakin menurun. Hal ini diduga dengan semakin banyaknya lapisan maka akan semakin banyak bidang permukaan celah pada balok laminasi, sehingga menyebabkan ikatan antar layer dengan perekat pada balok laminasi semakin kecil.

Peningkatan MOR rerata balok laminasi terhadap balok solid kayu Mahang ditunjukan pada variasi BL K2, yaitu sebesar 93,4\%. Hal ini berarti bahwa kayu Meranti memberikan perkuatan terhadap kayu Mahang jika jumlah layer yang digunakan hampir sama atau lebih besar dan dilakukan dengan model laminasi serta ditinjau dari nilai MORnya. Handayani (2016) menyatakan bahwa perkuatan dari kayu dengan mutu yang lebih tinggi pada sisi luar dibandingkan dengan kayu yang sisi dalam mampu memberikan ketahanan lentur yang lebih tinggi dibandingkan dengan ketahanan lentur dari kayu tanpa laminasi atau kayu solidnya.

Handayani (2016) juga menyatakan bahwa teknologi laminasi dengan perkuatan kayu yang lebih tinggi mutunya mampu memberikan peningkatan pemanfaatan pada kayu yang mutunya lebih rendah.

\section{2) Modulus Elastisitas (MOE)}

Menurut Risnasari (2012), modulus elastisitas (MOE) adalah ukuran ketahanan balok laminasi menahan beban dalam batas proporsinya. Sifat ini sangat penting jika balok laminasi digunakan sebagai bahan konstruksi. MOE merupakan sifat mekanis balok laminasi yang menunjukkan ketahanan terhadap pembengkokan akibat adanya beban yang diberikan sebelum balok laminasi patah.

Hasil pengujian MOE balok laminasi dan balok solid seperti yang ditunjukkan pada Gambar 15 terlihat bahwa nilai MOE rerata BL K1 sebesar 1516,01 Mpa, rerata BLK2 sebesar 2682,36 Mpa dan rerata BL K3 3107,74 Mpa.

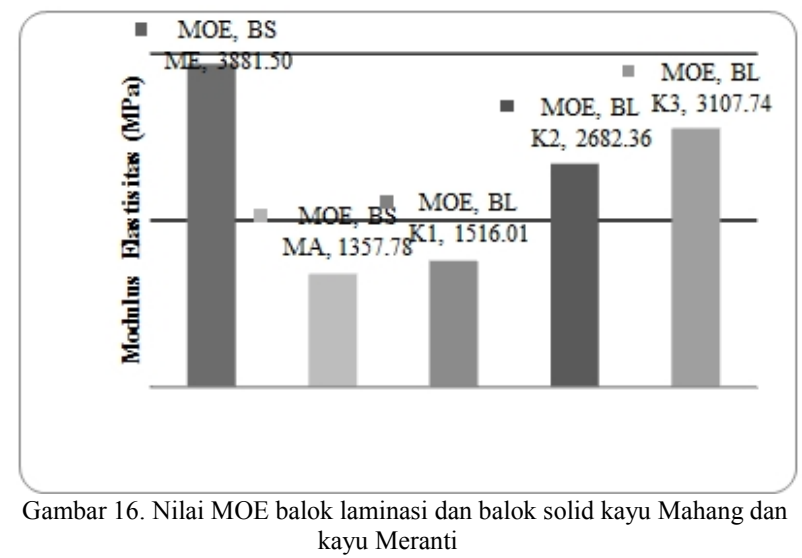

Dari Gambar 16 diketahui bahwa nilai rerata MOE pada semua variasi balok laminasi lebih besar dibanding dengan balok solid kayu Mahang (BS MA), tetapi lebih rendah jika dibandingkan dengan balok solid kayu Meranti (BS ME). Hal ini menunjukkan bahwa adanya penyusunan layer/lamina dengan cara mengkombinasikan jenis kayu yang memiliki berat jenis tinggi dengan kayu yang memiliki berat jenis rendah dalam proses pembuatan balok laminasi dapat menurunkan kualitas kayu yang pada awalnya memiliki berat jenis tinggi. Namun; prinsip tersebut dapat meningkatkan kualitas kayu dengan berat jenis rendah (Sari 2011).

\section{KESIMPULAN}

Dari hasil pengujian properties kayu Mahang dan kayu Meranti diketahui bahwa kayu Mahang punya mutu yang lebih rendah dibandingkan kayu Meranti.

Penggunaan kayu Meranti pada layer terluar (sebagai kayu mutu tinggi) dapat meningkatkan kapasitas lentur (MOR) balok laminasi kayu Mahang dan kayu Meranti.

Proporsi jumlah layer yang seimbang atau lebih antara kayu Meranti dan Mahang dapat meningkatkan nilai MOR dan MOE balok laminasi jika dibandingkan dengan balok solid yang memiliki berat jenis kayu yang rendah (Mahang).

\section{Ucapan Terima Kasih}

Terima kasih penulis sampaikan kepada Politeknik Negeri Bengkalis yang sudah 
memberikan dukungan berupa fasilitas untuk melakukan penelitian tentang balok laminasi ini. Terima kasih juga penulis sampaikan kepada mahasiswa (Debby Rizkia, A.Md) yang telah membantu dalam melaksanakan penelitian ini. Terima kasih juga saya sampaikan kepada jurnal Gradasi yang telah membantu menerbitkan paper ini. Akhir kata saya ucapkan semoga paper ini bisa menjadi salah satu referensi untuk menambah wawasan dalam bidang laminasi khususnya balok.

\section{REFERENSI}

B Al, Et Moody. 1999. Balok laminasi sebagai bahan struktural. Evalina Herawatil 2008, Universitas Sumatra Utara.

Anshari Buan. 2006. Pengaruh variasi tekanan kempa terhadap kuat lentur kayu laminasi dari kayu Meranti dan Keriung. Civil Engineering Dimension. Vol.8 No.1.

Awaludin ali. 2011. Penelitian sifat-sifat fisika dan mekanika kayu Glugu dan Sengon kawasan Merapi dalam rangka mempercepat pemulihan ekonomi masyarakat Merapi pasca letusan Merapi 2010. Diakses tanggal 10 Maret 2016, awaludin.staff.ugm.ac.id/files/2011/03

Awaludin, Ali dan Inggar Septhia I.(2005). Kontruksi Kayu. Jurusan Teknik Sipil. Universitas Gadjah Mada. Yogyakarta: Biro Penerbit.

Badan Standarisasi Nasional.(1994)) Metode Pengujian Kuat Tarik Kayu Di Laboratorium (SNI 03-3399-1994).BSN. Jakarta. Indonesia.

Badan Standarisasi Nasional.(1994) Metode Pengujian Kuat Geser Kayu Di Laboratorium. (SNI 03-3400-1994).BSN. Jakarta. Indonesia.

Badan Standarisasi Nasional.(1995) Metode Pengujian Kuat Tekan Kayu Di Laboratorium. (SNI 03-3958-1995).BSN. Jakarta. Indonesia.

Handayani S. 2016. Analisis Pengujian struktur balok laminasi kayu Sengon dan kayu Kelapa. Jurnal Teknik Sipil \& Perencanaan. No.1 Vol. 18

Haygreen J.G dan J.L Bowyer. 1996. Hasil hutan dan ilmu kayu (Terjemahan Sujipto, A.H). Gadjah Mada University Press. Yogyakarta.
Iensufrie, Tikno. (2009). Mengenal Teknik Pengeringan Kayu. Surabaya: Erlangga.

Puluhulawa I, dkk. 2018. Pengaruh Penambahan Baut Dan Paku Terhadap Kuat Lentur Balok Laminasi Kayu Mahang Dan Meranti. INERSIA. No.1. Vol.XIV

Risnasari I, Azhar I dan Sitompul A.N. 2012. Karakteristik balok laminasi dari batang kelapa (Cocos Nucifera L) dan kayu Kemiri (Aleurities Moluccana Wild). Foresta Indonesia Journal of Forestry. No.1. Vol.2

Sari Rima J. P. 2011. Karakteristik Balok laminasi dari kayu sengon, Manii, dan akasia. Institut Pertanian Bogor. 